\title{
Grassland carbon sequestration and emissions following cultivation in a mixed crop rotation
}

\author{
Bharat Sharma Acharya, Jim Rasmussen, Jørgen Eriksen* \\ Department of Agroecology, Aarhus University, PO Box 50, 8830 Tjele, Denmark
}

\section{A R T I C L E I N F O}

\section{Article history:}

Received 7 December 2011

Received in revised form 2 March 2012

Accepted 4 March 2012

\section{Keywords:}

Carbon sequestration

Grass-clover mixture

Grassland cultivation

Age

Management

\begin{abstract}
A B S T R A C T
Grasslands are potential carbon sinks to reduce unprecedented increase in atmospheric $\mathrm{CO}_{2}$. Effect of age (1-4-year-old) and management (slurry, grazing multispecies mixture) of a grass phase mixed crop rotation on carbon sequestration and emissions upon cultivation was compared with 17-year-old grassland and a pea field as reference. Aboveground and root biomass were determined and soils were incubated to study $\mathrm{CO}_{2}$ emissions after soil disturbance. Aboveground biomass was highest in 1-year-old grassland with slurry application and lowest in 4-year-old grassland without slurry application. Root biomass was highest in 4-year-old grassland, but all 1-4-year-old grasslands were in between the pea field $\left(0.81 \pm 0.094 \mathrm{~g} \mathrm{~kg}^{-1}\right.$ soil $)$ and the 17 -year-old grassland $\left(3.17 \pm 0.22 \mathrm{~g} \mathrm{~kg}^{-1}\right.$ soil $)$. Grazed grasslands had significantly higher root biomass than cut grasslands. There was no significant difference in the $\mathrm{CO}_{2}$ emissions within 1-4-year-old grasslands. Only the 17-year-old grassland showed markedly higher $\mathrm{CO}_{2}$ emissions ( $4.9 \pm 1.1 \mathrm{~g} \mathrm{CO}_{2} \mathrm{~kg}^{-1}$ soil). Differences in aboveground and root biomass did not affect $\mathrm{CO}_{2}$ emissions, and slurry application did not either. The substantial increase in root biomass with age but indifference in $\mathrm{CO}_{2}$ emissions across the age and management in temporary grasslands, thus, indicates potential for long-term sequestration of soil C.
\end{abstract}

(c) 2012 Elsevier B.V. All rights reserved.

\section{Introduction}

An unprecedented increase in the global atmospheric concentration of greenhouse gases since 1970, primarily due to the use of fossil fuels and land use changes have raised the global attention on the use of soils as potential sink for atmospheric $\mathrm{CO}_{2}$. Article 3.4 of the Kyoto Protocol allows the inclusion of soil organic carbon (SOC) as a mechanism to account and reduce the emissions of greenhouse gases (IPCC, 2007; Smith et al., 1997).

Storage of carbon in soils depends upon the $C$ inputs, rate of decomposition of SOM, soil texture and climate (Johnston et al., 2009). Carbon sequestration rates in temperate grasslands vary from negative (Schipper et al., 2007) to $8 \mathrm{MgCha}^{-1} \mathrm{yr}^{-1}$ (Jones and Donnelly, 2004) and are associated with large uncertainties (Soussana et al., 2004) arising from climatic variables (moisture and temperature), and temporal and spatial difference in sink capacities of ecosystems (Hutchinson et al., 2007). A model based estimate of terrestrial C sequestration by Thomson et al. (2008a,b) reported that the rate varies explicitly with time, technology and policy scenarios. Studies on $\mathrm{C}$ storage suggest that most of the $\mathrm{C}$ in

\footnotetext{
* Corresponding author. Tel.: +45 89991870.

E-mail address: jorgen.eriksen@agrsci.dk (J. Eriksen).
}

grasslands originates from below ground biomass (Hungate et al., 1997; Jackson et al., 2002), primarily roots (Adair et al., 2009). Larger roots may be more important compared to small roots to enhance $C$ pools (Rasmussen et al., 2010). Approximately 70-75\% of root biomass in grassland is concentrated in the upper $15 \mathrm{~cm}$ of the soil horizon (Gleixner et al., 2005). The root biomass increases with age of grassland. Maher et al. (2010) observed significant linear increase in root biomass with the age of grasslands from an experimental site in Iowa, USA. Estimates show that organic C in soil derived from roots of temperate arable land and grassland species during a growing season is in the range of $0.1-2.8 \mathrm{tha}^{-1}$; perennial ryegrass contributing to $2.8 \mathrm{tha}^{-1}$ (Rees et al., 2005).

Cultivated grasslands, also called rotational grasslands, are an important part of the agricultural system in Europe. With highly productive grass-clover mixtures, these grasslands store $C$ to form a vital part of the terrestrial reserve. However, these grasslands are temporary in nature and frequent cultivation makes SOM vulnerable to $C$ losses compared to permanent grasslands. Approximately, $20-30 \%$ of SOC in the top $30 \mathrm{~cm}$ of a soil horizon is susceptible to rapid losses due to frequent cultivation in temperate regions (Hutchinson et al., 2007). A range of field and laboratory studies have shown $\mathrm{C}$ emissions from temperate grassland to be affected by management practices (Ammann et al., 2007; Rees et al., 2005; Bol et al., 2003b). As C stocks respond differently to management 
practices, an increased $C$ sequestration is reported under intensive management, while extensive management of grassland is often associated with C losses (Ammann et al., 2007). Studies suggest that management options including fertilization, irrigation, inter-sowing of grasses and legumes, intensification of grazing, conservation tillage and crop rotation can enhance soil $\mathrm{C}$ pools (Conant et al., 2001; Hutchinson et al., 2007; Christopher, 2007; Paustian et al., 1997). However, C stocks in grasslands decline with overgrazing, less frequent cutting and invasive species (Maia et al., 2009; Elmore and Asner, 2006; Conant and Paustian, 2002; Ammann et al., 2007; Smith et al., 2008). C stocks in temperate grasslands increase significantly under management with single or multiple improvements. Ogle et al. (2004) estimated an increase in SOC of temperate grasslands by $14 \%$ under management with a single improvement (either fertilization or introduction of legume or irrigation) using linear mixed effect modeling. Management induced changes in $\mathrm{C}$ stocks are also climate dependent (Ogle et al., 2005) with higher loss of C stocks from tropical zones compared to moist or dry temperate zones under long term cultivation.

Intensively managed and fertilized grassland hold higher SOC than less managed grasslands (Conant et al., 2001). Similarly, application of organic manure increases SOC stocks compared to mineral fertilizers application (Yang et al., 2004; Jones et al., 2006). Bol et al. (2003a) also observed a higher quantity of water soluble organic C to a depth of $7.5 \mathrm{~cm}$ and enhanced enzymatic activities with slurry amendment compared to a control from temperate grassland in Southwest England. However, grasslands treated with slurry are also associated with increased $\mathrm{CO}_{2}$ emissions through respiration (Bol et al., 2003b).

Grazing, on the other hand, accelerates annual shoot turnover, adds organic $C$ in the form of animal excreta, and redistributes C within the plant-soil system (Reeder and Schuman, 2002; Franzluebbers and Stuedemann, 2003); this being essential for soil $C$ storage. The belowground biomass, dead root biomass and fine root productivity have been shown to increase with grazing compared to un-grazed sites (Pucheta et al., 2004). The estimated return of ingested biomass in the form of animal excreta during grazing is approximately $40 \%$ (Soussana et al., 2004). In contrast, exclusion of grazing leads to immobilization of $\mathrm{C}$, reduced growth of fibrous roots and consecutively lower C stocks (Reeder and Schuman, 2002). In the US, grazing management of rangelands is estimated to increase $C$ stocks from 0.1 to $0.3 \mathrm{MgCha}^{-1} \mathrm{yr}^{-1}$ (Schuman et al., 2002). However, grazing also induces $\mathrm{CO}_{2}$ emissions due to increased microbial activities (Pucheta et al., 2004), and increase in soil temperature and respiration resulting from reduced leaf area and increased penetration of light into the soil surface (Bremer et al., 1998). On the whole, C sequestration is favored by increased $C$ inputs like plant residues and below-ground biomass, for which introduction of deep rooted grasses are decisive (Singh, 2008). Carbon in grass based pastures, if allocated below the plough layer, is protected from oxidation losses (Fisher et al., 1994).

The effect of management on soil $C$ sequestration and emissions in cultivated grasslands of agricultural systems, alone or coupled with age of grassland, remains poorly understood. This study aimed to elucidate the effect of age and management on $C$ sequestration and emissions following cultivation in a mixed crop rotation through the analysis of above and below-ground biomass, soil respiration and dissolved organic $\mathrm{C}$. We hypothesized that the age and management practices would affect $C$ storage and emissions in grasslands upon cultivation. Specifically, we hypothesized that (1) root biomass would increase with age of grasslands, (2) $\mathrm{CO}_{2}$ emissions following cultivation would increase with slurry application and age of grassland, but still with a net storage of $\mathrm{C}$ in soil and (3) $\mathrm{CO}_{2}$ emissions following cultivation of grazed grassland would exceed those of a mowed grasslands.

\section{Materials and methods}

\subsection{Site}

The study was undertaken in experimental site Folumgaard located at the Research Centre Foulum in the central part of Jutland, Denmark $\left(9^{\circ} 34^{\prime} \mathrm{E}, 56^{\circ} 29^{\prime} \mathrm{N}\right)$ with an annual mean precipitation of $770 \mathrm{~mm}$ and an annual mean temperature of $7.7^{\circ} \mathrm{C}$. The soil type was classified as Typic Hapludult, according to the USDA Soil Taxonomy System (Møberg and Nielsen, 1986) with $7.4 \%$ clay, $10 \%$ silt, $81 \%$ sand and $1.6 \% \mathrm{C}$ in the topsoil $(0-20 \mathrm{~cm})$. The mixed crop rotation was established in 1987, when a six-year rotation (undersown barley - grass-clover - grass-clover - barley/pea - winter wheat or oats - fodder beets) replaced cereal cropping (Eriksen et al., 2004). In 2006/2007, 3- and 4-year-old grass-clover was introduced in the six-year crop rotation (undersown barley - four years of grass-clover - barley). Thus, the 1-4-year-old grasslands sampled in this experiment in 2010 were established (undersown in barley) in 2006-2009. The mixed crop rotation contained 1-4-year-old grasslands in a replicated design and an un-replicated permanent grassland (17-year-old). Furthermore, an adjacent pea field following maize was used as reference.

\subsection{Field experiment}

Experimental treatments were arranged in a block design with four replications and a plot size of $9 \mathrm{~m} \times 15 \mathrm{~m}$. Pasture mixtures of the 1-4-year-old grasslands contained a basic mixture that included perennial ryegrass [Lolium perenne L.], white clover [Trifolium repens L.] and red clover [Trifolium pretense L.]. The 1-4year-old grasslands either remained without slurry or received $200 \mathrm{~kg}$ total-N ha ${ }^{-1}$ in cattle slurry every year, half injected in April and half immediately following a harvest in late May. To circumvent $\mathrm{K}$ deficiency previously reported at this site (Askegaard et al., 2003), a K-rich organic fertilizer with $21 \% \mathrm{~K}$ and $16 \% \mathrm{~S}$ was added to all plots. Thus, in 1-4-year-old grasslands were investigated in a factorial experiment the effect of grassland age and slurry application. Furthermore, the 4 year grasslands were comprised of two additional grasslands, either (a) grazing of the basic mixture or (b) sown as multiple species mixture for mowing. The treatment with multi species mixture contained the basic mixtures, 8 herbs, festulolium and Lucerne [Medicago sativa]. Two adjacent grasslands (a) a 17-year-old grazed grassland (white clover/ryegrass) and (b) an unfertilized pea field were selected as reference. The reference plots were, however, excluded from statistical analysis.

Aboveground biomass was harvested 4 times in $3 \mathrm{~m} \times 6 \mathrm{~m}$ plots: in June, July, August, and October 2010 by cutting crops at $5 \mathrm{~cm}$ stubble height. The biomass was dried at $60^{\circ} \mathrm{C}$ and weighed to obtain total dry matter yield (DM). Biomass was also partitioned for botanical composition of the pasture mixtures.

\subsection{Soil sampling and analysis}

During 25th October to 27th October 2010 soils were sampled to $20 \mathrm{~cm}$ using an auger with an inner diameter of $2 \mathrm{~cm}$. Each replicate was bulked from 40 sub-samples taken randomly to overcome soil heterogeneity. A total of forty seven samples with an average weight of $3.5 \mathrm{~kg}$ each were taken from the ten treatments (three replicates for the 17-year old grassland). All samples were taken to laboratory and stored at $2{ }^{\circ} \mathrm{C}$ until handling. Splitting of soil samples was accomplished within a week to get sub-samples for different analysis as shown in Fig. 1.

Soil samples were divided using a Riffle splitter (Fig. 1) to obtain $500 \mathrm{~g}, 200 \mathrm{~g}$ and $100 \mathrm{~g}$ of sample. Remaining soil was stored at $2{ }^{\circ} \mathrm{C}$ and later, at the end of the incubation study, analyzed for dissolved organic carbon (DOC). The $500 \mathrm{~g}$ and $100 \mathrm{~g}$ samples were used to 


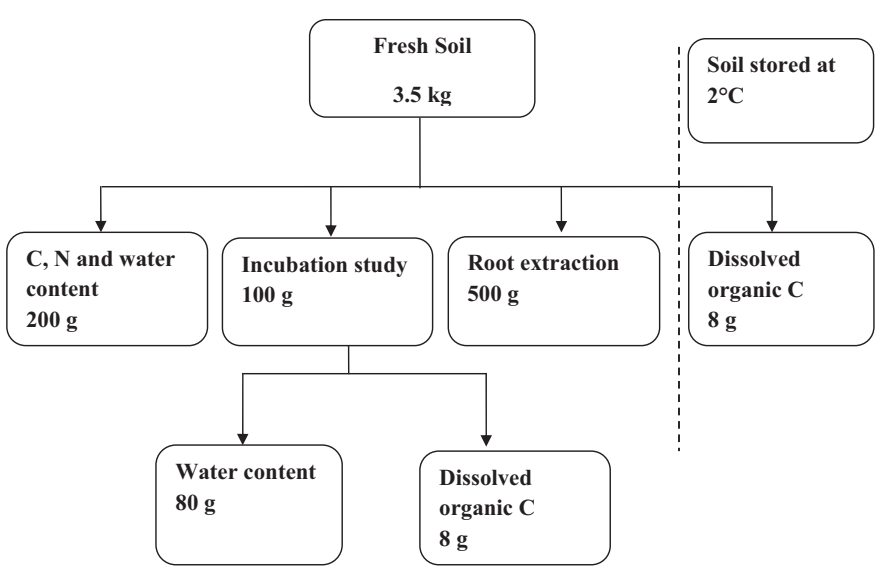

Fig. 1. Overview of sub-sampling of the soil. Sub-samples obtained were used to recover root biomass, and to analyze $\mathrm{CO}_{2}$ emission under incubation, soil carbon and nitrogen, water content, and DOC.

determine belowground root biomass and soil respiration respectively. Gravimetric water, $C$ and $N$ concentration were determined using the $200 \mathrm{~g}$ sample. Gravimetric water content was determined by oven drying soil samples for $48 \mathrm{~h}$ at $80^{\circ} \mathrm{C}$. Soils were ball milled and analyzed for C and N concentration on a LECO CNS-1000 analyzer [LECO Corporation, St Joseph, MI].

\subsection{Soil respiration and respirometer}

Soil samples were incubated field moist containing $60-65 \%$ of water holding capacity and the water content was maintained throughout the incubation period with demineralized water. The $\mathrm{CO}_{2}$ evolution from soil samples was determined using a respirometer [RESPICOND VI], a modified version of apparatus described by Nordgren (1988). $\mathrm{CO}_{2}$ evolution was determined on an hourly basis under incubation at $20^{\circ} \mathrm{C}$ for 120 days ( 1 st November 2010 to 3rd March 2011). Un-sieved soil samples (100 g) were packed in stainless steel cylinders and kept in separate plastic jars. Briefly, in the respirometer the $\mathrm{CO}_{2}$ respired from the soil is trapped in a potassium hydroxide $(\mathrm{KOH})$ solution where carbonate ions are formed changing the conductivity of the $\mathrm{KOH}$ solution. Carbonate ions posses higher ionic mobility compared to the hydroxide ions (Watts et al., 2000). The change in conductivity is measured over platinum electrodes by a conductometer and signals are transferred from conductometer to computer to calibrate total $\mathrm{CO}_{2}$ and accumulated $\mathrm{CO}_{2}$ as a measure of respiration. The apparatus was adjusted for finite capacity of $\mathrm{KOH}$ to absorb $\mathrm{CO}_{2}$ via water jet pump and dispenser (Nordgren, 1988, 1992; Thomson et al., 2008a,b).

\subsection{Root biomass}

Roots were isolated by wet sieving $500 \mathrm{~g}$ of soil with a gentle spray of water over a fine mesh screen of $125 \mu \mathrm{m}$ sieve, with repeated decantation to remove soil adhering to roots. Roots were collected in finely woven silk organza and dried in an oven at $70^{\circ} \mathrm{C}$ for $48 \mathrm{~h}$ to determine total root biomass (Rasmussen et al., 2010). No stratification was made based upon root length, root diameter and living or dead biomass.

\subsection{Dissolved organic carbon (DOC)}

At the end of the incubation study soil samples were divided on a Riffle splitter to obtain $8 \mathrm{~g}$ of sample. Likewise, soil stored at $2{ }^{\circ} \mathrm{C}$ was divided using a Riffle splitter to obtain $8 \mathrm{~g}$ samples.

Water soluble compounds were extracted by shaking $8 \mathrm{~g}$ of soil with $40 \mathrm{ml}$ of $1 \mathrm{mM} \mathrm{CaCl}$ for $2 \mathrm{~h}$ on a shaker at $200 \mathrm{rpm}$ followed by centrifugation at $5000 \mathrm{rpm}$ for $20 \mathrm{~min}$ and membrane filtration $(0.45 \mathrm{~mm})$ using the method of Marschner (2000). DOC was analyzed using a TOC-V analyzer (Shimadzu, UK).

\subsection{Statistical analysis}

Statistical analysis was performed for 1-4-year-old experimental grasslands across the effect of slurry application, age, and the interaction between age and slurry application. Differently treated 4-year-old grasslands were also analyzed separately to study the effect of slurry, multispecies mixture and grazing on different variables. Data were analyzed using the General Linear Model (GLM) procedure in SAS (SAS Institute Inc., 1999) and means were compared using the least significant difference at the $p=0.05$ level.

\section{Result}

\subsection{Aboveground and below ground root biomass}

Aboveground biomass was highest in 1-year-old grassland with slurry application and lowest in 4-year-old grassland without slurry application, corresponding to $12,600 \pm 460 \mathrm{~kg} \mathrm{DM} \mathrm{ha}^{-1}$ and $8900 \pm 100 \mathrm{~kg} \mathrm{DM} \mathrm{ha}^{-1}$, respectively (Fig. 2). Overall, the difference

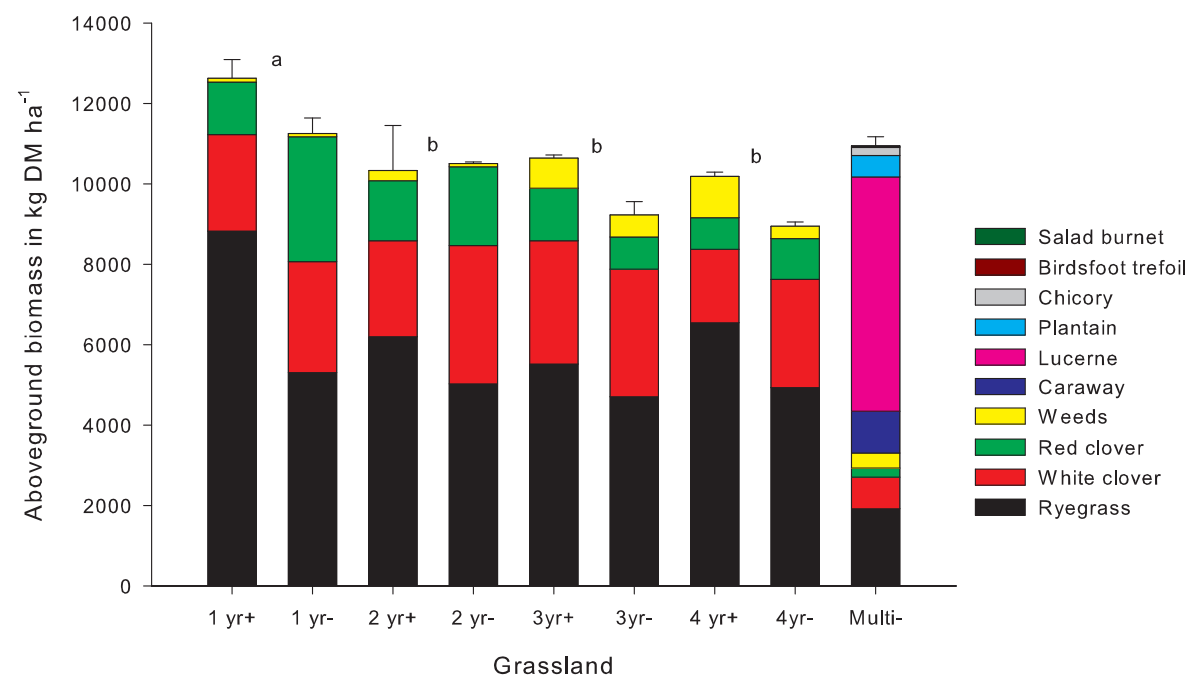

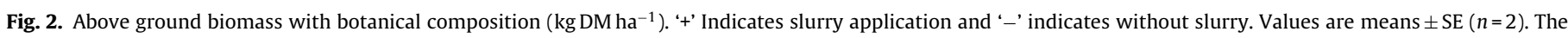
different letters between the bars indicates statistically different ages at $p=0.05$. 


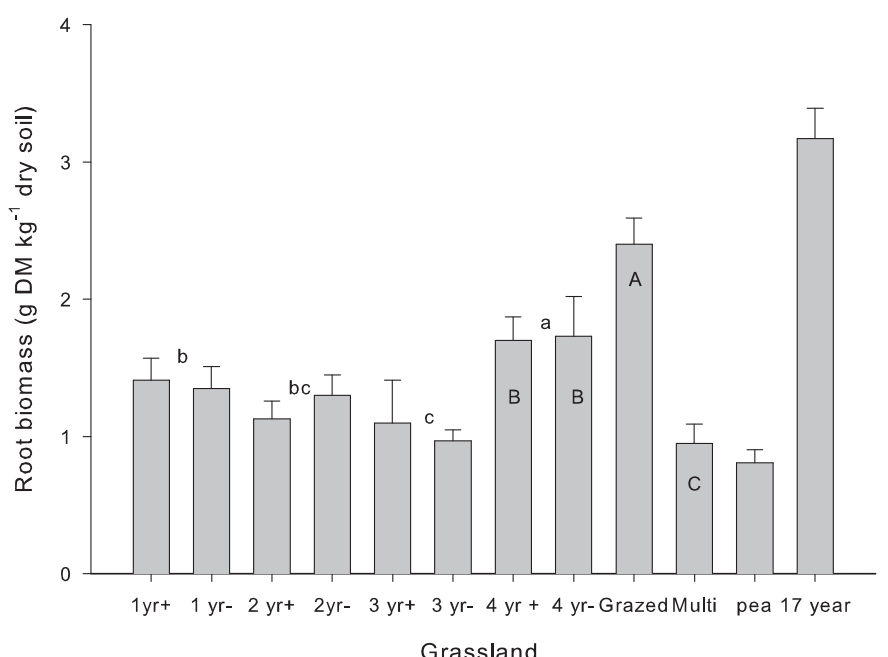

Fig. 3. Root biomass recovered from temperate grassland with grass clover mixtures ( $\mathrm{g}$ root DM kg-1 of dry soil). '+' Indicates slurry application and '-' indicates without slurry. Values are means $\pm \operatorname{SE}$ ( $n=3$ for 17 years, $n=4$ for all others). The different letters in between the bars indicates statistically different ages at $p=0.05$. The bars with different capital letters are statistically different at $p=0.05$ within the different 4 years old grassland.

in DM yield was small within the grasslands. L. perenne was the dominant species in most treatments (except in grassland with multispecies mixture), significantly decreasing with age $(p=0.02)$ and slurry application $(p<0.0001$; Fig. 2$)$. Aboveground biomass was significantly different $(p=0.04)$ among 1 -4-year-old grasslands. Aboveground DM yield of 1-year-old grasslands was significantly higher than remaining ages.

The highest and lowest root biomass was recovered from the 17-year-old grassland and pea field respectively, corresponding to $3.17 \pm 0.22$ and $0.81 \pm 0.094 \mathrm{~g}$ root $\mathrm{DM} \mathrm{kg}^{-1}$ of dry soil, respectively; both of these plots were reference plots not included in the statistical analysis. Root DM from 4-year-old grassland was significantly greater than 1,2 and 3-year-old grasslands. Root DM in 1st and 2nd year was significantly greater than 3-year-old grasslands. Grazed 4-year-old grassland had significantly greater root DM than either multispecies mixture, with or without slurry application. Grass-

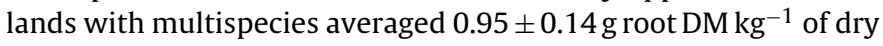
soil (Fig. 3). There was no significant effect on root DM of with and without slurry application among 1-4-year-old grasslands.

\section{2. $C / N$ ratio in root and soil samples}

The $\mathrm{C} / \mathrm{N}$ ratio of soil and root samples in the $0-20 \mathrm{~cm}$ soil layer ranged between $11.5 \pm 0.3$ to $12.3 \pm 0.1$ and $16.1 \pm 0.4$ to $19 \pm 1.1$, respectively (Table 1 ). There was no significant difference in the $\mathrm{C} / \mathrm{N}$ ratio of soil samples among 1 -4-year-old grasslands. However, the $\mathrm{C} / \mathrm{N}$ ratio of roots from 1 -year-old grasslands was significantly greater than 3-year-old grasslands. Slurry application had no significant influence on $\mathrm{C} / \mathrm{N}$ ratio of root and soil samples. The most significant effect of slurry application was evident on soil $\mathrm{C}$ $(p=0.008)$ and $\mathrm{N}(p=0.006)$ content.

\subsection{Soil respiration}

Soil respiration potential was determined after simulated grassland cultivation. Fig. 4 shows that accumulated $\mathrm{CO}_{2}$ increased non-linearly with days of incubation. Over the 120 days of incubation, accumulated $\mathrm{CO}_{2}$ was highest in the 17-year-old grassland $\left(4.9 \pm 1.1 \mathrm{~g} \mathrm{CO}_{2} \mathrm{~kg}^{-1}\right.$ dry soil) and lowest in the pea field $\left(2.5 \pm 0.2 \mathrm{~g} \mathrm{CO}_{2} \mathrm{~kg}^{-1}\right.$ dry soil) (Table 1$)$. There was no significant difference in $\mathrm{CO}_{2}$ across the age, slurry application and interaction between slurry application and age of grasslands. No significant effect of slurry was observed within the different 4-year-old grasslands (Fig. 4).

\subsection{Dissolved organic carbon (DOC)}

The DOC content in stored and incubated soil samples ranged from 19 to 25 and 24 to $27 \mathrm{mg} \mathrm{kg}^{-1}$, respectively. However, we observed no significant difference in DOC content of stored and incubated soil samples across the age (1-4-year-old grasslands), slurry application, and interaction between age and slurry. Meanwhile, DOC content increased in soil samples incubated at $20^{\circ} \mathrm{C}$ compared to soil samples stored at $2{ }^{\circ} \mathrm{C}$ (Table 1 ).

\section{Discussion}

Grasslands have received considerable attention for their C sink capacity (Conant et al., 2001), but they are dynamic and release $\mathrm{CO}_{2}$ as a response to management practices (Soussana et al., 2004; Ammann et al., 2007). The capacity of cultivated grasslands with grass-clover mixtures to store $C$ has been reported to lie in-between cropland and permanent grassland (Soussana et al., 2004). Roots are key components of $C$ sequestration due to their longer residence time in soils (Rasse et al., 2005). Total root biomass of 1-4-year-old grasslands recovered from our study was between 0.8 and $3 \mathrm{~g}$ root $\mathrm{DM} \mathrm{kg}^{-1}$ of dry soil from the pea field and 17year-old grassland, respectively. Although root biomass showed no distinct trend with age, we observed that the 4-year-old grasslands had significantly greater root biomass than younger age. The 3-year-old grassland had significantly lower root biomass than others (Fig. 3), which was unexpected. But it should be noted that root biomass is often affected by root recovery methods (Ping et al., 2010) and possibly fluctuates throughout the year (Pucheta et al., 2004). Exclusion of the 3-year-old grasslands, however, resulted in an increasing trend of root biomass with age of grassland $\left(R^{2}=0.85\right)$. Root biomass, in general, increases with age of grassland, because they are not harvested or removed as aboveground biomass. Moreover, perennial plants in grasslands have different rooting patterns and root $\mathrm{C}$ and $\mathrm{N}$ allocation strategies than annual crops, which have a continuous production and mortality of roots. Also, root production in annual crops occurs within certain growth stages of crops and ceases, whereas perennials have a more continuous root production. Root biomass in the present study was recovered by wet sieving, which can be biased to the loss of fine roots and root hairs (Huss-Danell et al., 2007).

Our results showed that within the different 4-year-old grasslands, root DM in multi species was significantly lower than the grazed grassland and grasslands applied with or without slurry. The grassland with multispecies was dominated by lucerne (Fig. 2). Because of the tap roots of lucerne, we speculate that our sampling method (auger with inner diameter $2 \mathrm{~cm}$ ) did not capture adequate and representative root biomass from these plots. Ping et al. (2010) also measured lower root biomass of grasses mixture and lucerne, respectively, during soil sampling using an auger compared to soil monoliths.

The root biomass from 4-year-old grassland with grazing was significantly greater than cut 4-year-old grassland with and without slurry application. Increase in root biomass with grazing was reported in an earlier study by Pucheta et al. (2004). Pucheta et al. (2004) recorded a trend for greater fine root productivity and total belowground biomass in grazed sites compared to no grazing for grasslands in central Argentina. Sites with no grazing are often subjected to lower root density and lower development of fibrous roots (Reeder and Schuman, 2002). 
Table 1

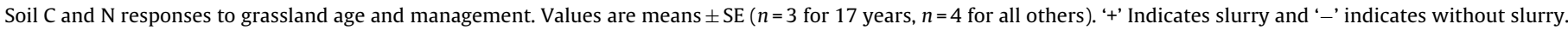

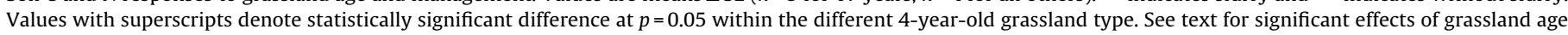
and slurry application.

\begin{tabular}{|c|c|c|c|c|c|c|c|}
\hline \multirow[t]{2}{*}{ Grassland age } & \multirow[t]{2}{*}{ Treatment } & \multirow[t]{2}{*}{$\mathrm{C} / \mathrm{N}$ ratio root } & \multirow[t]{2}{*}{$\mathrm{C} / \mathrm{N}$ ratio soil } & \multirow{2}{*}{$\begin{array}{l}\text { Soil C } \\
\mathrm{g} \mathrm{kg}^{-1}\end{array}$} & DOC stored soil & DOC incub. soil & Acc. $\mathrm{CO}_{2}$ \\
\hline & & & & & \multicolumn{3}{|c|}{ (mg kg ${ }^{-1}$ dry soil) } \\
\hline \multirow[t]{2}{*}{ 1-year-old } & -Slurry & $17.7 \pm 0.2$ & $12.3 \pm 0.1$ & $19 \pm 0.09$ & $19.6 \pm 1.3$ & $25 \pm 0.8$ & $3136 \pm 162$ \\
\hline & +Slurry & $17.8 \pm 0.2$ & $11.5 \pm 0.3$ & $20 \pm 1.35$ & $23.5 \pm 1.4$ & $27.3 \pm 1.6$ & $3282 \pm 338$ \\
\hline \multirow[t]{2}{*}{ 2-year-old } & -Slurry & $16.8 \pm 1$ & $11.9 \pm 0.1$ & $20 \pm 0.02$ & $20.4 \pm 0.6$ & $27.2 \pm 1.2$ & $2634 \pm 322$ \\
\hline & +Slurry & $16.8 \pm 0.4$ & $12.1 \pm 0.04$ & $21 \pm 0.04$ & $21.7 \pm 1$ & $26 \pm 0.9$ & $2824 \pm 222$ \\
\hline \multirow[t]{2}{*}{ 3-year-old } & -Slurry & $17.1 \pm 0.3$ & $12.1 \pm 0.2$ & $19 \pm 0.05$ & $21 \pm 0.8$ & $24.2 \pm 0.4$ & $2706 \pm 499$ \\
\hline & +Slurry & $16.1 \pm 0.4$ & $12 \pm 0.2$ & $21 \pm 0.06$ & $21.4 \pm 2.7$ & $25 \pm 2$ & $2703 \pm 221$ \\
\hline \multirow[t]{4}{*}{ 4-year-old } & -Slurry & $17.6 \pm 0.4^{\mathrm{ab}}$ & $12.1 \pm 0.3$ & $19 \pm 0.03$ & $19.2 \pm 2.1$ & $26.4 \pm 0.3$ & $2564 \pm 129$ \\
\hline & +Slurry & $17 \pm 0.2^{\mathrm{b}}$ & $12.2 \pm 0.2$ & $20 \pm 0.06$ & $22.1 \pm 1.7$ & $26.3 \pm 1.2$ & $2689 \pm 95$ \\
\hline & Multi. mix & $16.8 \pm 0.6^{\mathrm{b}}$ & $11.9 \pm 0.2$ & $19 \pm 0.04$ & $22 \pm 3$ & $24 \pm 1$ & $2729 \pm 88$ \\
\hline & Grazed & $19.4 \pm 1.1^{\mathrm{a}}$ & $12 \pm 0.2$ & $20 \pm 0.06$ & $23.1 \pm 1.5$ & $26 \pm 0.8$ & $2597 \pm 175$ \\
\hline Pea field & & $17.5 \pm 0.3$ & $11.6 \pm 0.1$ & $16 \pm 0.05$ & $21.2 \pm 0.5$ & $22 \pm 0.8$ & $2524 \pm 222$ \\
\hline 17-year-old & & $18.1 \pm 1.1$ & $11.9 \pm 0.1$ & $22 \pm 0.64$ & $24.7 \pm 2.8$ & $27.3 \pm 3.5$ & $4904 \pm 1088$ \\
\hline
\end{tabular}

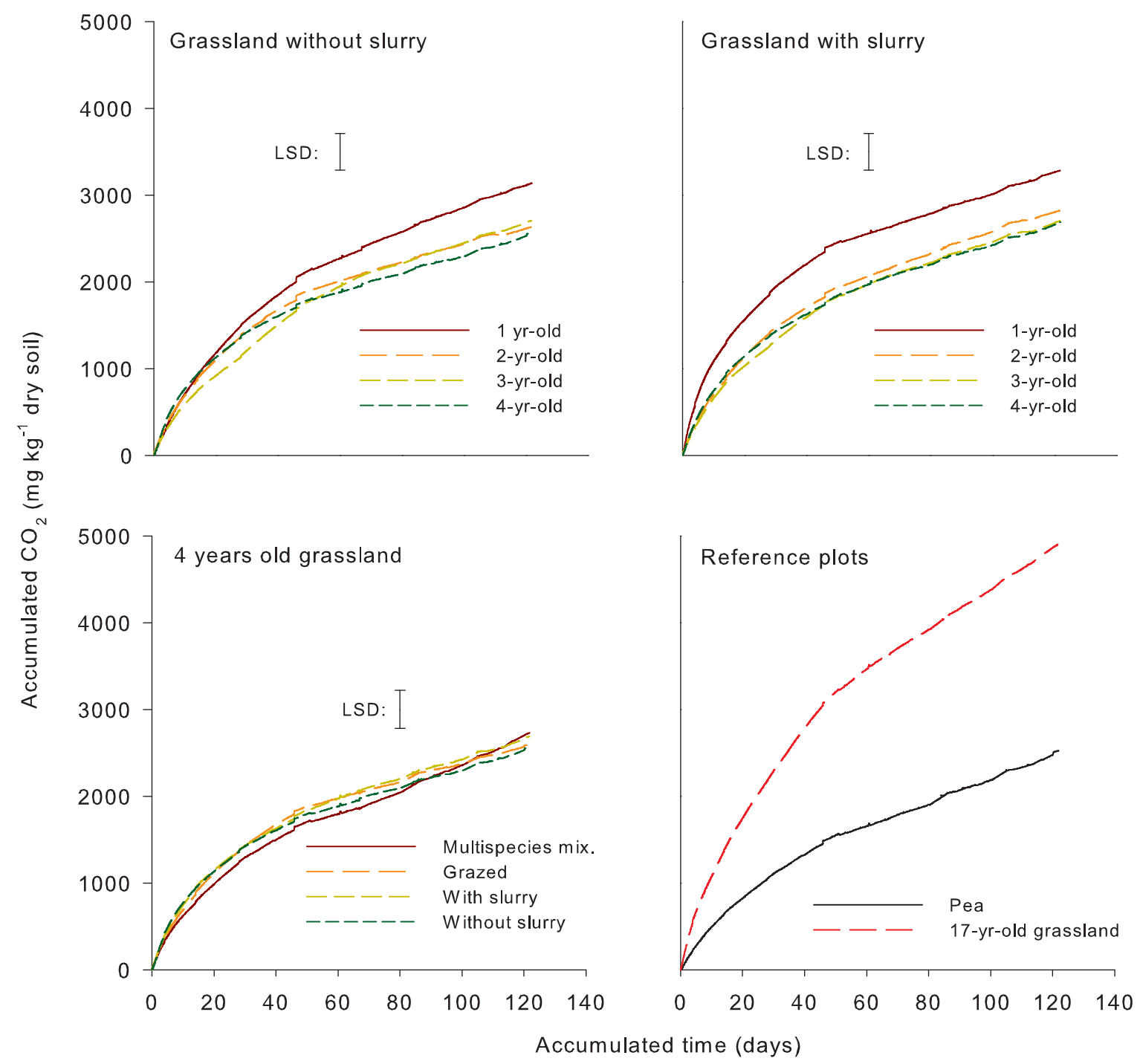

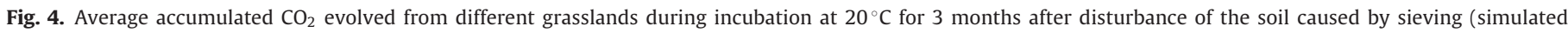
ploughing). '+' Indicates slurry application and '-' indicates without slurry. LSD = least significant difference $(p=0.05)$.

Total aboveground DM production in the present study was in agreement with the findings of Høgh-Jensen and Schjoerring (2001), who recorded 7000 and $11,000 \mathrm{~kg} \mathrm{DM} \mathrm{ha}^{-1}$ yield of ryegrass community grown with white clover and red clover, respectively.
Mallarino and Wedin (1990) reported total DM production of legumes-grass mixtures between 7000 and $12,000 \mathrm{~kg} \mathrm{DM} \mathrm{ha}^{-1}$. We observed greater aboveground biomass in 1-year-old grasslands compared to other ages. Such tendency is often governed by the 
photosynthetic activity of plants, which declines rapidly with the age of plant as a result of declining stomatal conductance (Gower et al., 1996).

The $\mathrm{C} / \mathrm{N}$ ratio of roots of 1 -year-old grasslands was significantly greater than 3-year-old grasslands with and without slurry. This disparity in $\mathrm{C} / \mathrm{N}$ ratio of roots is attributable to the botanical composition of the grassland species. The notable difference in white clover across different ages may have affected the $\mathrm{C} / \mathrm{N}$ ratio (Fig. 2). This stoloniferous crop contains higher $\mathrm{N}$ content in roots (Askegaard and Eriksen, 2007). The 3-year-old grassland had relatively greater white clover composition ( $~ 30 \%$ of DM) than the 1 -year-old grassland ( $\sim 20 \%$ of DM), which provided substantially higher $\mathrm{N}$. We also found that the interaction of age and slurry had significant influence on the $\mathrm{C} / \mathrm{N}$ ratio of soil. Animal manure has a residual effect and $\mathrm{N}$ is slowly released to be available for plants in later years (Chadwick and Chen, 2002). The effect of slurry on soil C and $\mathrm{N}$ rely upon the quantity of slurry applied, and mineralization and build-up of SOM.

The DOC concentration in extracts was in agreement with the findings of Blagodatskaya et al. (2011), who recorded DOC of $13-26 \mathrm{mg} \mathrm{kg}^{-1}$ in the upper $10 \mathrm{~cm}$ of soil from experimental grasslands in Germany. Although we observed no significant difference in DOC concentration among treatments, it would be expected that DOC concentration declines after incubation of soil due to utilization of DOC by soil microorganisms (Marschner and Noble, 2000). However, we observed an increase in DOC when incubated at $20^{\circ} \mathrm{C}$ compared to $2{ }^{\circ} \mathrm{C}$. Temperature has been shown to influence DOC, in which higher temperature may produce soluble compounds and hydrophilic acids that increase the DOC concentration (Christ and David, 1996).

$\mathrm{CO}_{2}$ emissions in permanent grasslands have been reported to be greater than in cultivated grasslands (Plante et al., 2011). Over the 120 days of incubation, we observed that the 17 -year-old grassland showed markedly higher $\mathrm{CO}_{2}$ emissions from 1-4-year-old grassland upon cultivation. However, we observed no significant difference in accumulated $\mathrm{CO}_{2}$ among 1-4-year-old grasslands. Although the difference in age among grasslands may have been too small to show an effect (Maher et al., 2010), our results indicates that the build-up of $C$ in grassland soil increases with grassland age, which was supported by the results in Franzluebbers and Stuedemann (2003). No significant difference in $\mathrm{CO}_{2}$ emissions was observed with slurry application, which was consistent with the results for poultry manure applied in grassland (Franzluebbers and Stuedemann, 2003). However, in a study from two grasslands in the UK there was a strong correlation between slurry incorporation and $\mathrm{CO}_{2}$ emissions (Bol et al., 2003b). Our study did not support the hypothesis that grazing induces higher $\mathrm{CO}_{2}$ emission and thus have a larger labile $C$ pool than cut grasslands, in spite of the grazed grassland having higher root biomass. This finding is even more surprising given the high return of $\mathrm{C}$ and $\mathrm{N}$ from grazing animals compared to removal of plant biomass occurring with the mowing treatments. Grazing has been shown to increase the microbial population due to increasing fine root biomass (Pucheta et al., 2004), surface area of roots (Toal et al., 2000) and deposition of cattle manure (Franzluebbers and Stuedemann, 2003); all increasing soil respiration. Furthermore, greater amounts of fine roots in grazed grasslands would additionally be associated with increased rhizo-deposition and root turnover rates (Bardgett et al., 1998). Hence, in the present study the age of grassland was more important than other management factors in inducing greater root biomass build-up without enhancing loss of $\mathrm{C}$ via respiration after sward plough-in. Therefore, a considerable $\mathrm{C}$ sequestration should be expected with increasing grassland age, although the effect would likely stabilize with time, as shown by the greater respiration in the 17 -year old grassland.

\section{Conclusion}

Aboveground DM yield and root biomass were significantly affected by age of grassland. There was an increasing trend of root biomass with age of grasslands, when excluding the 3-yearold grasslands. Our study did not support the hypothesis that $\mathrm{CO}_{2}$ emissions increase with slurry application and age of grasslands. Furthermore, above ground DM yield and root DM showed no significant difference with slurry application. Similarly, there was no significant difference in $\mathrm{CO}_{2}$ emissions between grazed and cut grasslands. Only the 17-year-old grassland showed markedly higher $\mathrm{CO}_{2}$ emissions. Because $\mathrm{CO}_{2}$ emissions following cultivation were independent of management practices, we conclude that $C$ sequestration would depend to a greater extent upon the age of grassland. Quantifying the role of these grasslands should include studies on other greenhouse gases to give a comprehensive picture of the climate change mitigation. Further studies across larger variation in age of cultivated grasslands will be essential to provide further insights into the effect of management on $C$ storage and emissions.

\section{Acknowledgements}

This work was part of the Organic RDD programme, coordinated by International Centre for Research in Organic Food Systems, ICROFS and funded by The Danish AgriFish Agency, Ministry of Food, Agriculture and Fisheries.

\section{References}

Adair, E.C., Reich, P.B., Hobbie, S.E., Knops, J.M.H., 2009. Interactive effects of time, $\mathrm{CO}_{2}, \mathrm{~N}$, and diversity on total belowground carbon allocation and ecosystem carbon storage in a grassland community. Ecosystems 12, 1037-1052.

Ammann, C., Flechard, C.R., Leifeld, J., Neftel, A., Fuhrer, J., 2007. The carbon budget of newely established temperate grassland depends on management intensity. Agric. Ecosyst. Environ. 121, 5-20.

Askegaard, M., Eriksen, J., 2007. Growth of legume and non legume catch crops and residual $\mathrm{N}$ effects in spring barley on coarse sand. J. Plant Nutr. Soil Sci. 170, $773-780$.

Askegaard, M., Eriksen, J., Olesen, J.E., 2003. Exchangeable potassium and potassium balances in organic crop rotations on a coarse sand. Soil Use Manage. 19, 96-103.

Bardgett, R.D., Wardle, D.A., Yeates, G.W., 1998. Linking above ground and belowground interactions: how plant responses to foliar herbivory influence soil organisms. Soil Biol. Biochem. 30, 1867-1878.

Blagodatskaya, E., Yuyukina, T., Blagodatsky, S., Kuzyakov, Y., 2011. Turnover of soil organic matter and of microbial biomass under C3 \& C4 vegetation change: consideration of ${ }^{13} \mathrm{C}$ fractionation and preferential substrate utilization. Soil Biol. Biochem. 43, 159-166.

Bol, R., Kandeler, E., Amelung, W., Glaser, B., Marx, M.C., Preedy, N., Lorenz, K., 2003a. Short-term effects of dairy slurry amendment on soil carbons sequestration and enzymatic activities in a temperate grassland. Soil Biol. Biochem. 35, 1411-1421.

Bol, R., Moering, J., Kuzyakov, Y., Amelung, W., 2003b. Quantification of priming and $\mathrm{CO}_{2}$ respiration sources following slurry-C incorporation into two grassland soils with different C content. Rapid Commun. Mass Spectrom. 17, 2585-2590.

Bremer, D.J., Ham, J.M., Owensby, C.E., Knapp, A.K., 1998. Responses of soil respiration to clipping and grazing in a tall grass prairie. J. Environ. Qual. 27, 1539-1548.

Chadwick, D.R., Chen, S., 2002. Manures. In: Haygarth, P.M., Jarvis, S.C. (Eds.), Agriculture, Hydrology and Water Quality. CABI Publishing, UK, pp. 57-83.

Christ, M.J., David, M.B., 1996. Temperature and moisture effects on the production of dissolved organic carbon in a spodosol. Soil Biol. Biochem. 32, 47-57.

Christopher, S.F., 2007. Nitrogen management affects carbon sequestration in North American cropland soils. Crit. Rev. Plant Sci. 26, 45-64.

Conant, R.T., Paustian, K., 2002. Potential soil carbon sequestration in overgrazed grassland ecosystems. Global Biogeochem. Cycles 16, 1143.

Conant, R.T., Paustian, K., Elliott, E.T., 2001. Grassland management and conversion into grassland: effects on soil carbon. Ecol. Appl. 11, 343-355.

Elmore, A.J., Asner, G.P., 2006. Effect of grazing intensity on soil carbon stocks following deforestation of a Hawaiian dry tropical forest. Global Change Biol. 12, 1761-1772.

Eriksen, J., Askegaard, M., Kristensen, K., 2004. Nitrate leaching from an organic dairy crop rotation: the effects of manure type nitrogen input and improved crop rotation. Soil Use Manage. 20, 48-54.

Fisher, M.J., Rao, I.M., Ayarza, M.A., Lascano, C.E., Sanz, J.I., Thomas, R.J., Vera, R.R. 1994. Carbon storage by introduced deep-rooted grasses in the South American savannas. Nature 371, 236-238. 
Franzluebbers, A.J., Stuedemann, J.A., 2003. Bermudagrass management in the Southern Piechmont USA. III. Particulate and biologically active soil carbon. Soil Sci. Soc. Am. J. 67, 132-138.

Gleixner, G., Kramer, C., Hahn, V., Sachse, D., 2005. The effect of biodiversity on carbon storage in soils. In: Scherer-Lorenzen, M., Korner, C., Schulze, E.D. (Eds.), Forest Diversity and Functions: Temperate and Boreal Systems. Springer, Berlin, pp. 165-183.

Gower, S.T., McMurtrie, R.E., Murty, D., 1996. Aboveground net primary production decline with stand age: potential causes. Trends Ecol. Evol. 11, 378-382.

Høgh-Jensen, H., Schjoerring, J.K., 2001. Rhizodeposition of nitrogen by red clover white clover and ryegrass leys. Soil Biol. Biochem. 33, 439-448.

Hungate, B.A., Holland, E.A., Jackson, R.B., Chapin, F.S., Mooney, H.A., Field, C.B., 1997. The fate of carbon in grasslands under carbon dioxide enrichment. Nature 388, 576-579.

Huss-Danell, K., Chaia, E., Carlsson, G., 2007. $\mathrm{N}_{2}$ fixation and nitrogen allocation to above and below ground plant parts in red clover-grasslands. Plant Soil 299, $215-226$.

Hutchinson, J.J., Campbell, C.A., Desjardins, R.L., 2007. Some perspectives on carbon sequestration in agriculture. Agric. For. Meterol. 142, 288-302.

Intergovernmental Panel on Climate Change (IPCC), 2007. In: Metz, B., Davidson, O.R., Bosch, P.R., Dave, R., Meyers, L.A. (Eds.), Climate change 2007: mitigation. Contribution of Working Group III to the Fourth Assessment Report of the Inter governmental Panel on Climate Change. Cambridge University Press, Cambridge, UK and New York, USA

Jackson, R.B., Banner, J.L., Jobbagy, E.G., Pockman, W.T., Wall, D.H., 2002. Ecosystem carbon loss with woody plant invasion of grasslands. Nature 418, 623-626.

Johnston, A.E., Poulton, P.R., Coleman, K., 2009. Soil organic matter: its importance in sustainable agriculture and carbon dioxide fluxes. Adv. Agron. 101, 1-57.

Jones, M.B., Donnelly, A., 2004. Carbon sequestration in temperate grassland ecosystems and the influence of management climate and elevated $\mathrm{CO}_{2}$. New Phytol. $164,423-439$.

Jones, S.K., Rees, R.M., Kosmas, D., Ball, B.C., Skiba, U.M., 2006. Carbon sequestration in temperate grassland; management and climate controls. Soil Use Manage. 22, $132-142$.

Maia, S.M.F., Ogle, S.M., Cerri, C.E.P., Cerri, C.C., 2009. Effect of grassland management on soil carbon sequestration in Rondonia and Mato Grosso states Brazil. Geoderma 149, 84-91.

Mallarino, A.P., Wedin, W.F., 1990. Effect of species and proportion of legume on herbage yield and nitrogen concentration of legume-grass mixtures. Grass Forage Sci. 45, 393-402.

Marschner, B., Noble, A.D., 2000. Chemical and biological processes leading to the neutralization of acidity in soil incubated with litter materials. Soil Biol. Biochem. $32,805-813$

Maher, R.M., Asbjornsen, H., Kolka, R.K., Cambardella, C.A., Raich, J.W., 2010. Changes in soil respiration across a chronosequence of tallgrass prairie reconstructions. Agric. Ecosyst. Environ. 139, 749-753.

Møberg, J.P., Nielsen, J.D., 1986. The constituent composition of soils from Danish State Agricultural Research Stations. Tidsskrift for Planteavl no. S1870. Danish Institute of Plant and Soil Science.

Nordgren, A., 1988. Apparatus for the continuous long-term monitoring of soil respiration rate in large numbers of samples. Soil Biol. Biochem. 20, 955-957.

Nordgren, A., 1992. A method for determining microbially available $\mathrm{N}$ and $\mathrm{P}$ in an organic soil. Biol. Fertil. Soils 13, 195-199.

Ogle, S.M., Breidt, F.J., Paustain, K., 2005. Agricultural management impacts on soil organic carbon storage under moist and dry climatic conditions of temperate and tropical regions. Biogeochemistry 72, 87-121.
Ogle, S.M., Conant, R.T., Paustain, K., 2004. Deriving grassland management factors for a carbon accounting method developed by the International Panel on Climate Change. Environ. Manage. 33, 474-484.

Pucheta, E., Bonamici, I., Cabido, M., Diaz, S., 2004. Below-ground biomass and productivity of a grazed site and a neighbouring ungrazed exclosure in a grassland in central Argentina. Aust. Ecol. 29, 201-2008.

Paustian, K., Andren, O., Janzen, H.H., Lal, R., Smith, P., Tian, G., Tiessen, H., Van Noordwijk, M., Woomer, P.L., 1997. Agricultural soils as a sink to mitigate $\mathrm{CO}_{2}$ emissions. Soil Use Manage. 13, 230-244.

Ping, X., Zhou, G., Zhuang, Q., Wang, Y., Zuo, W., Shi, G., Lin, X., Wang, Y., 2010. Effects of sample size and position from monolith and core methods on the estimation of total root biomass in a temperate grassland ecosystem. Geoderma 155, 262-268.

Plante, A.F., Fernández, J.M., Haddix, M.L., Steinweg, J.M., Conant, R.T., 2011. Biologi$\mathrm{cal}$, chemical and thermal indices of soil organic matter stability in four grassland soils. Soil Biol. Biochem. 43, 1051-1058.

Rasmussen, J., Eriksen, J., Jensen, E.S., Jensen, H.H., 2010. Root size fractions of ryegrass and clover contribute differently to $\mathrm{C}$ and $\mathrm{N}$ inclusion in SOM. Biol. Fertil. Soils 46, 293-297.

Rasse, D.P., Rumpel, C., Dignac, M., 2005. Is soil carbon mostly root carbon? Mechanism for a specific stabilization. Plant Soil 269, 341-356.

Reeder, J.D., Schuman, G.E., 2002. Influence of livestock grazing on C sequestration in semi arid mixed grass and short grass rangelands. Environ. Pollut. 116, 457-463.

Rees, R.M., Bingham, I.J., Baddeley, J.A., Watson, C.A., 2005. The role of plants and land management in sequestration soil carbon in temperate arable and grassland ecosystems. Geoderma 128, 130-154.

SAS Institute Inc., 1999. SAS/STAT Software. Release 8.02. SAS Institute Inc., Cary, NC, USA.

Schuman, G.E., Janzen, H.H., Herrick, J.E., 2002. Soil carbon dynamics and potential carbon sequestration by rangelands. Environ. Pollut. 116, 391-396.

Schipper, L.A., Basdon, W.T., Parfitt, R.L., Ross, C., Claydon, J.J., Arnold, C., 2007. Large losses of soil $\mathrm{C}$ and $\mathrm{N}$ from soil profiles under pasture in New Zealand during the past 20 years. Global Change Biol. 13, 1138-1144.

Singh, B.R., 2008. Carbon sequestration in soils of cool temperate regions (introductory and editorial). Nutr. Cycl. Agroecosyst. 81, 107-112.

Smith, P., Martino, D., Cai, Z., Gwary, D., Janzen, H., Kumar, P., McCarl, P., Ogle, S., O’Mara, F., Rice, C., Scholes, B., Sirotenko, O., Howden, M., McAllister, T., Pan, G., Romanenkov, V., Schneider, U., Towprayoon, S., Wattenbach, M., Smith, J., 2008. Greenhouse gas mitigation in agriculture. Philos. Trans. R. Soc. B. 363, 789-813.

Smith, P., Powlson, D.S., Glendining, M.J., Smith, J.U., 1997. Potential for carbon sequestration in European soils: preliminary estimates for five scenarios using results from long-term experiments. Global Change Biol. 3, 67-79.

Soussana, J.F., Loiseau, P., Vuichard, N., Ceschia, E., Balesdent, J., Chevallier, T., Arrouays, D., 2004. Carbon cycling and sequestration oppourtunities in temperate grasslands. Soil Use Manage. 20, 219-230.

Thomson, A.M., Izaurralde, R.C., Smith, S.J., Clarke, L.E., 2008a. Integrated estimates of global terrestrial carbon sequestration. Global Environ. Change 18, 192-203.

Thomson, I.K., Kruse, T., Bruun, S., Kristiansen, S.M., Knicker, H., Petersen, S.O., Jensen, L.S., Holst, M.K., Christensen, B.T., 2008b. Characteristics of soil carbon buried for 3300 years in a Bronze Age burial mound. Soil Sci. Am. J. 72, 1292-1298.

Toal, M.E., Yeomans, C., Killham, K., Meharg, A.A., 2000. A review of rhizosphere carbon flow modelling. Plant Soil 222, 263-281.

Watts, C.W., Eich, S., Dexter, A.R., 2000. Effect of mechanical energy inputs on soil respiration at the aggregate and field scales. Soil Tillage Res. 53, 231-243.

Yang, Z., Singh, B.R., Sitaula, B.K., 2004. Fractions of organic carbon in soils under different crop rotations cover crops and fertilization practices. Nutr. Cycl. Agroecosyst. $70,161-166$ 